\title{
Pengaruh Ngulat Tipat Taluh terhadap Keterampilan Motorik Halus Anak Usia 6-7 Tahun
}

\author{
Made Padma Dewi Bajirani dan L.K. Pande Ary Susilawati \\ Program Studi Psikologi, Fakultas Kedokteran, Universitas Udayana \\ bajirani@gmail.com
}

\begin{abstract}
Abstrak
Keterampilan motorik halus merupakan keterampilan yang sangat penting diperlukan dalam perkembangan anak. Pelatihan dan pengembangan terhadap keterampilan motorik halus juga mulai dikembangkan. Namun masih sedikit sekali ditemukan pengembangan terhadap keterampilan motorik halus anak melalui media kebudayaan yang disesuaikan dengan daerahnya masing-masing. Dalam kebudayaan Bali, salah satu media yang dapat digunakan adalah ngulat tipat taluh. Maka berdasarkan permasalahan di atas, adapun tujuan dari penelitian ini adalah untuk mengetahui pengaruh ngulat tipat khususnya tipat taluh terhadap keterampilan motorik halus anak usia 6-7 tahun.

Penelitian ini menggunakan metode eksperimen dengan rancangan one-group pre-test post-test design dengan jumlah subyek sebanyak 49 orang. Pengumpulan data dalam penelitian ini dilakukan melalui pengukuran variabel keterampilan motorik halus sebanyak dua kali yaitu pada saat pre-test dan post-test. Alat ukur yang digunakan berupa maze yang terdiri dari 8 buah aitem maze. Setelah melakukan uji validitas dan reliabilitas, maka setiap aitem maze dikatakan valid dengan nilai rix bergerak pada rentangan 0,298 sampai dengan 0,712 dengan nilai koefisien reliabilitas Alpha Cronbach $(\alpha)$ sebesar 0,812 . Berdasarkan hasil uji statistik T-test paired yang dilakukan, nilai signifikansi (2tailed $) \leq 0,025(\alpha=0,025)$ yaitu 0,00 dan nilai t hitung pada penelitian ini adalah 6,603 lebih besar dari t table 1,677. Maka dapat diambil keputusan bahwa hipotesa alternatif (Ha) diterima yaitu terdapat pengaruh ngulat tipat taluh terhadap keterampilan motorik halus anak usia 6-7 tahun.
\end{abstract}

Kata kunci : Ngulat tipat taluh, keterampilan motorik halus, anak usia 6-7 tahun.

\begin{abstract}
Fine motor skills are very important skills that needed in child development and it require training and skills to be developed. However, there are only few of fine motor skills development which based on culture and uses traditional activities to be the tool to improve the child's fine motor skills. In Balinese culture, one of activities which can be used to develop fine motor skill is ngulat tipat taluh. Based on this problem, the aim of this study was to determine the effect of ngulat tipat taluh to fine motor skills in children aged 6-7 years.

This study used an experimental method with one-group pre-test post-test design with 49 people as subject. Data in this study was collected by measuring fine motor skills variable in pre-test and post-test. The measurement is using mazes that consist of 8 items, and after the validity and reliability test each items was valid with rix in range 0.298 to 0.712 and alpha cronbach reliability coefficient $(\alpha)$ is 0.812 . Based on the results of the statistical paired T-test, the value of significance (2-tailed) $0.00 \leq 0.025(\alpha=0.025)$ and the $t$ value in this study was 6.603 greater than $t$ table $(1.677)$. Based on statistical analysis, it can be concluded that the alternative hypothesis (Ha) can be accepted and there was significant influence ngulat tipat taluh to fine motor skills in 6-7 years old children.
\end{abstract}

Keywords: Ngulat tipat taluh, fine motor skills, children aged 6-7 years. 


\section{LATAR BELAKANG}

Setiap individu akan mengalami perkembangan sehingga menjadi seorang pribadi yang ada saat ini. Proses perkembangan manusia ini terdiri dari beberapa fase termasuk di dalamnya fase perkembangan anak-anak (Hughes, 2002; Santrock, 2002). Pada setiap tahapan perkembangan anak terdapat beberapa aspek perkembangan yang bertumbuh kembang secara kompleks, memiliki karakteristik yang berbeda sesuai dengan tahapan usianya masing-masing (Papalia, Olds, \& Fieldman, 2008). Aspek-aspek tersebut meliputi perkembangan fisik atau biologis, perkembangan kognitif, dan perkembangan sosio- emosional (Papalia, Olds, \& Fieldman, 2009; Santrock, 2012). Seperti halnya pada usia 6 atau 7 tahun yang tercakup dalam middle childhood, anak mulai memasuki pendidikan formal sesungguhnya yaitu sekolah dasar. Pada usia ini, anak mengalami transisi dari taman kanak-kanak menuju sekolah dasar (Hartingsveld, Groot, Aarts, \& Sanden, 2011) dengan tuntutan dan tanggung jawab yang berbeda dan lebih besar dibandingkan dengan usia sebelumnya. Salah satunya adalah anak dituntut untuk mampu memenuhi kompetensi secara akademis dan sosial (Hughes, 2002) yang melibatkan kesiapan perkembangan aspek fisik, kognitif dan sosio-emosional yang matang sesuai dengan tahapan perkembangan anak.

Namun Soetjiningsih (2012) mengemukakan bahwa dalam kehidupan sehari-hari sebagian besar orang tua dan juga sekolah masih sangat menekankan pada perkembangan aspek kognitif dan cenderung melupakan aspek perkembangan lainnya. Sesungguhnya impilikasi dalam optimalisasi perkembangan anak tidak hanya berpegang pada salah satu aspek perkembangan saja. Ketiga aspek perkembangan yaitu fisk, kognitif dan sosio- emosianal anak memiliki peranannya masing-masing dan saling terintegrasi maupun mempengaruhi satu sama lain (Soetjiningsih, 2012). Hambatan yang terjadi pada salah satu aspek tidak akan hanya berdampak pada perkembangan aspek tersebut di kemudian hari melainkan juga menghambat perkembangan aspek lainnya. Oleh karena itu, ketiga aspek perkembangan ini harus mendapatkan perhatian dan stimulasi yang memadai agar dapat berkembang secara optimal tidak terkecuali perkembangan motorik halus atau fine motor yang merupakan bagian dari perkembangan fisik anak.

Keterampilan motorik halus atau fine motor skills merupakan salah satu bagian dari perkembangan motorik anak yang melibatkan perkembangan otot-otot halus, kepekaan motorik, koordinasi antara mata dan tangan, kesabaran serta pengambilan keputusan (Hughes, 2002). Keterampilan motorik halus pada anak dapat diobservasi melalui pergerakan tangan dan jari-jari seperti dalam kegiatan memakai baju, memasang tali sepatu dan kancing baju, menggunting, menggambar maupun menulis (Hughes, 2002; Isbell, 2010b; Santrock, 2002). Keterampilan motorik halus melibatkan 2 (dua) komponen utama yaitu eye-hand coordination atau koordinasi mata dengan tangan, serta finger dexterity atau ketangkasan jari-jemari (Virginia School Health Guidelines, 1994). Selain itu keterampilan motorik halus dapat ditingkatkan melalui 4 (empat) aspek yaitu kecepatan, keakuratan, kestabilan dan kekuatan melalui aktivitasaktivitas yang melibatkan keterampilan tangan di dalamnya (Hurlock, 1995). Keterampilan motorik halus memiliki peranan yang penting yang selanjutnya akan membangun rasa percaya diri ketika anak mampu menyelesaikan tugastugas menulis maupun menggambar yang diberikan. Kepercayaan diri yang dimiliki oleh anak inilah yang kemudian akan mempengaruhi kemampuan sosialnya (Bredecamp \& Copple dalam Isbell, 2010a). Selain itu dampak daripada kegagalan anak dalam mencapai keterampilan dasar motorik halus sesuai dengan tahapan usianya juga akan memunculkan stres dan rasa frustrasi pada anak yang akan berdampak langsung pada performa di sekolah dan kemampuan sosial (McHale \& Cermak dalam Feder \& Majnemer, 2007; Hartingsveld, Groot, Aarts, \& Sanden, 2011).

Kurangnya perhatian khusus dan stimulus yang berarti pada keterampilan motorik halus saat masa anak-anak, akan menjadikan meningkatnya resiko akan gangguan perkembangan motorik pada anak. Sampai saat ini, tercatat terdapat peningkatan jumlah anak yang mengalami masalah dalam merencanakan dan memunculkan respon terhadap keterampilan motorik termasuk di dalamnya gangguan keterampilan motorik halus. Berdasarkan penelitian Wright dan Sugden yang dilakukan di Singapura pada tahun 1996 terdapat sekitar $1,4 \%$ sampai dengan $4 \%$ anak usia 6-9 tahun mengalami kesulitan dalam koordinasi motorik pada anak usia sekolah (Nelson \& Jaskiewicz, 2012). Penelitian lainnya juga menyatakan bahwa diperkirakan sekitar $12 \%$ anak mengalami kesulitan pada area keterampilan motorik halus (NCBTP, 2008). Padahal anak-anak usia sekolah menghabiskan sekitar $60-70 \%$ waktunya di sekolah. Pada sisi yang berbeda khususnya di Indonesia, pada usia 6 atau 7 tahun anak mulai memasuki sekolah dasar dimana untuk memasuki sekolah dasar anak diwajibkan untuk bisa membaca, menulis, dan menghitung (Munawwaroh, 2012). Hal ini menjadikan banyak anak yang memerlukan kesiapan pada setiap aspek perkembangan untuk memenuhi tuntutan saat memasuki sekolah dasar. Menurut Ratih (dalam Munawwaroh, 2012), sekitar $60 \%$ dari kliennya yang melakukan konseling adalah anak usia sekolah dan sebagian besar diantaranya mengalami stres. Salah satu penyebab stres pada adalah ketidaksiapan anak dengan segala tuntutan inipun akan memicu terjadinya stres pada anak yang semakin diperkuat lagi akibat kekhawatiran orangtua pada anak sehingga memunculkan tekanan dalam bentuk paksaan pada anak (Anna, 2012). Di sisi lain perkembangan teknologi dan kemajuan zaman yang 
sangat pesat menjadikan anak-anak pada masa kini sangat jarang melakukan kegiatan yang melibatkan keterampilan motorik halus maupun kasar (Kantha, Boonchai, \& Krairach, 2012). Kehidupan anak-anak pra sekolah maupun telah sekolah khususnya di daerah industri atau berkembang, kini juga mencerminkan banyaknya kegiatan yang dilakukan dengan bantuan mesin dan anak kurang aktif dalam menggunakan keterampilan tangannya (Laoakka, Karnjanangkura, \& Suwapeat, 2009). Hal ini tentu saja akan berdampak besar tehadap keterampilan motorik halus anak serta performa anak ketika memasuki sekolah dasar dan bagaimana nantinya perkembangan anak dalam mengikuti proses belajar mengajar di sekolahnya dengan sekian banyak kompetensi yang harus dipenuhi.

Melihat pentingnya peranan keterampilan motorik halus menjadikan banyaknya pengembangan yang dilakukan untuk mengembangkan dan meningkatkan kemampuan motorik halus (Isbell, 2010a). Pelatihan dan pengembangan terhadap keterampilan motorik halus diharapkan dapat disesuaikan dengan budaya setempat sehingga nantinya anak mengetahui dan sekaligus belajar akan tugas dan kewajibannya di masa perkembangan yang lebih matang (McHale \& Cermak dalam Feder \& Majnemer, 2007). Permainan tradisional yang mengangkat budaya-budaya lokal juga mulai dicanangkan kembali dan masuk dalam kurikulum sekolah seperti petak umpet, galasin, dampu, lentengan, lompat tali, cutik, congkak dan bekel (Puspayanti, 2009). Permainan tradisional juga memiliki manfaat yang sama baiknya dengan permainan adaptasi, seperti mengembangkan kemampuan motorik halus dan kasar pada anak (Suhamah dalam Puspayanti, 2009).

Seperti halnya daerah lain di seluruh Indonesia, Bali memiliki beragam budaya dan permainan tradisional. Salah satu budaya Bali yang dapat dijumpai dalam kehidupan masyarakat sehari-hari adalah tipat. Tipat (ketupat) merupakan salah satu makanan yang masih ada dan sering digunakan dalam upacara keagamaan di Bali (Kusumawardhani, 2010). Sebelum menghasilkan tipat, maka sebelumnya terdapat proses membuat ketupat atau yang biasa disebut sebagai ngulat tipat (Kusuma, 1956; Anandakusuma, 1986). Ngulat tipat memiliki tingkatan kerumitan yang berbeda-beda tergantung pada jenis ketupat yang dibuat. Tingkat kerumitan anyaman pada ngulat tipat juga memberikan manfaat bagi pembuatnya maupun penikmatnya seperti melatih jari-jemari (Budiari, 2012). Ngulat tipat juga memiliki manfaat untuk melatih konsentrasi seseorang, karena saat membuat ketupat seseorang akan terfokus untuk menganyam janur sehingga mencapai bentuk ketupat yang diharapkan (Budiari, 2012; Karda 2003). Kebudayaan Hindu di Bali sendiri memiliki berbagai jenis ketupat yang sering digunakan dalam kehidupan sehari- hari, salah satu jenisnya adalah tipat taluh (ketupat berbentuk telur). Tipat taluh merupakan jenis ketupat yang mudah untuk dibuat, tidak memiliki proses yang rumit dan menggunakan bahan yang sederhana. Proses pembuatan ketupat ini hanya memerlukan 4 tahapan yang terdiri dari proses membuat lingkaran, menganyam hingga mepet atau merapatkan (Raras, 2007). Menurut Budiari (2012), jenis ketupat ini biasa diajarkan pada anak-anak usia awal sekolah dasar.

Berdasarkan uraian di atas peneliti menggunakan ngulat tipat taluh sebagai salah satu bentuk pengaplikasian kebudayaan Bali untuk melatih, mengasah dan mengembangkan keterampilan motorik halus. Maka dari itu tujuan dari penelitian ini adalah melihat pengaruh ngulat tipat taluh terhadap keterampilan motorik halus anak usia 6-7 tahun, mengetahui seberapa besar pengaruh ngulat tipat taluh terhadap keterampilan motorik halus anak usia 6-7 tahun, serta melihat bagaimana pengaruh ngulat tipat taluh terhadap keterampilan motorik halus anak usia 6-7 tahun.

\section{METODE}

Berdasarkan tujuan penelitian ini, maka terdapat hipotesis mayor dan minor dalam penelitian yang menjadi asumsi dalam penelitian ini diantaranya adalah terdapat pengaruh ngulat tipat taluh terhadap keterampilan motorik halus anak usia 6-7 tahun. Sedangkan hipotesis minor dalam penelitian ini adalah terdapat pengaruh ngulat tipat taluh terhadap aspek keakuratan dan kekuatan pada keterampilan motorik halus anak usia 6-7 tahun dan terdapat pengaruh ngulat tipat taluh terhadap aspek kecepatan dan kestabilan pada keterampilan motorik halus anak usia 6-7 tahun.

Penelitian ini menggunakan pendekatan kuantitatif dengan rancangan pre- experimental yaitu rancangan pre-test dan post-test pada satu kelompok (one-group pre- test post-test design). Rancangan ini mencakup satu kelompok yang diobservasi pada tahap pre-test yang kemudian dilanjutkan dengan tritmen atau perlakuan dan diakhiri dengan post-test (Creswell, 2010).

\section{Variabel dan definisi operasional}

Adapun identifikasi variabel-variabel penelitian berdasarkan fungsinya yang terdapat dalam penelitian ini yaitu ngulat tipat taluh sebagai variabel bebas dan Keterampilan motorik halus pada anak usia 6-7 tahun sebagai variabel tergantung. Berikut adalah definisi operasional beberapa variabel dalam penelitian ini.

\section{Definisi Operasional Ngulat Tipat Taluh}

Ngulat tipat taluh adalah proses pembuatan ketupat berbentuk telur yang dibuat dengan menggunakan 1 lembar janur (daun pohon kelapa yang masih muda) dengan panjang $90 \mathrm{~cm}$ dan lebar $2,5 \mathrm{~cm}$. Ngulat tipat taluh dalam perlakuan 
terdiri dari 4 tahapan yaitu: 1.) membuat 2 buah lipatan berbentuk lingkaran, 2.) selanjutnya lingkaran yang satu dimasukkan setengah kedalam lingkaran kedua, 3.) setelah dimasukkan, ujung janur pertama dimasukkan ke lubang yang berseberangan kemudian ujung janur kedua dimasukkan ke lubang yang berseberangan lainnya, 4.) ulatan yang sudah jadi kemudian dirapatkan dengan cara menarik sisi-sisinya hingga rapat. Keempat tahapan di atas diberikan secara bertahap selama 4 hari pertemuan dengan proses modeling atau menirukan diawal perlakuan hingga subyek mampu mengerjakannya sendiri di akhir perlakuan.

2. Definisi Operasional Keterampilan motorik halus pada anak usia 6-7 tahun

Keterampilan motorik halus pada anak usia 6-7 tahun adalah kemampuan anak usia 6-7 tahun dalam mengatur gerakannya secara halus yang melibatkan tangan, jari-jari, dan lengan yang memiliki 2 komponen di dalamnya yaitu koordinasi mata dan tangan (eye- hand coordination) dan ketangkasan jari-jari (finger dexterity). Keterampilan motorik halus dalam penelitian ini, terukur melalui aspek kecepatan, keakuratan, kestabilan dan kekuatan. Keterampilan motorik halus pada anak usia 6-7 tahun dalam penelitian ini akan diukur menggunakan alat ukur keterampilan motorik halus berbentuk maze dengan menghitung jumlah waktu dan error (kesalahan) dalam menyelesaikannya. Pengukuran ini nantinya akan dilakukan secara individual dan diberikan 2 (dua) kali yakni pre-test dan post-test dengan alat ukur yang sama.

\section{Respoanden}

Subyek dalam penelitian ini berjumlah 49 orang yang memiliki kriteria inklusi dalam penelitian ini. Beberapa kriteria inklusi pada subyek yang digunakan dalam penelitian ini antara lain:

a. Anak memiliki usia kronologis di atas atau sama dengan 6 tahun (72 bulan) dan tidak lebih dari 7,5 tahun (90 bulan). Usia kronologis akan terhitung mulai dari tanggal kelahiran anak hingga tanggal dilakukannya post-test terhadap keterampilan motorik halus.

b. Berjenis kelamin perempuan maupun laki-laki.

c. Berdomisili di Bali.

d. Bersedia menjadi subyek penelitian dengan mengisi inform concent yang diwakili oleh sekolah selaku institusi pendidikan.

Sedangkan beberapa kriteria eksklusi pada subyek yang digunakan dalam penelitian ini antara lain:

a. Subyek tidak mengikuti keseluruhan rangkaian pelaksanaan penelitian yang terdiri dari pre-test, perlakuan sebanyak 4 kali pertemuan, dan post-test. b. Subyek tidak hadir pada salah satu rangkaian pelaksanaan pengambilan data penelitian.

c. Subyek melakukan izin keluar pada saat pemberian perlakuan pelatihan ngulat tipat taluh.

Seluruh subyek dalam penelitian ini ditentukan berdasarkan metode pengambilan sampel yaitu cluster sampling yang merupakan bagian dari probability sampling (Kerlinger, 2006; Myers \& Hansen, 2006; Sugiyono, 2012b). Pada penelitian ini, pemilihan sampel tahap pertama dilakukan untuk memilih himpunan yang lebih kecil yaitu sekolah dasar yang dipilih secara acak, dan tahap kedua menentukan sampel pada sekolah tersebut yang memiliki kriteria inklusi secara acak pula.

\section{Tempat penelitian}

Penelitian ini dilakukan pada SD Negeri 2 Panjer, Denpasar, Bali yang dilaksanakan pada bulan Februari sampai dengan bulan Maret 2013.

\section{Alat ukur}

Alat ukur yang digunakan dalam penelitian ini adalah maze dengan tujuan untuk mengukur keterampilan motorik halus pada anak usia 6-7 tahun. Penelitian ini mengadaptasi cara pengukuran dan sistem skoring terhadap keterampilan motorik halus pada beberapa penelitian sebelumnya yaitu penelitian dari Stoeger, Zigegler, dan Martzog (2008). Peneliti juga mengadaptasi cara pengukuran dan skoring pada bagian sub test maze yang salah satunya digunakan untuk mengukur koordinasi visual motorik serta ketepatan dan kecepatan kerja pada tes psikologis yaitu WPPSI (Wechsler Preschool and Primary Scale of Intelligence).

Maze adalah salah satu jenis tour-puzzle atau puzzle 2 dimensi yang menuntut pemainnya menelusuri melalui jalan-jalan bercabang dan sulit untuk dinavigasi, dimulai pada titik awal (start) hingga sampai pada titik akhir (finish) (Rabani, 2011). Berdasarkan beberapa klasifikasi jenis maze yang ada, peneliti melakukan kombinasi terhadap ketiga tipe maze yang ditinjau dari jalur lintasannya untuk membentuk maze dengan tingkat kesulitan yang berbeda-beda. Penelitian ini menggunakan 8 (delapan) buah gambar maze 2 dimensi yang memiliki tingkat kesulitan termudah hingga tersulit. Keterampilan motorik halus ini akan diukur berdasarkan 2 faktor yakni eye-hand coordination dan finger dexterity. Masing-masing faktor juga mengukur 4 aspek keterampilan motorik halus. Empat aspek tersebut adalah kecepatan, keakuratan, kestabilan dan kekuatan yang nantinya akan terukur melalui indikator waktu dalam satuan second atau detik dan jumlah error. Adapun gambaran umum atau blue-print maze untuk mengukur keterampilan motorik halus dapat dilihat pada tabel berikut: 
Tabel 1.

Blue print Keterampilan Motorik Halus

\begin{tabular}{llllcc}
\hline \multicolumn{1}{c}{ Domain } & \multicolumn{1}{c}{ Atribut } & \multicolumn{1}{c}{ Aspek } & \multicolumn{1}{c}{ Indikator } & Bobot & Item \\
\hline Keterampilan & Eye-hand & Kecepatan & Jumalah waktu & $25 \%$ & \\
motorik & Coordination & Keakuratan & Jumlah error & $25 \%$ & Maze 1-8 \\
Halus & dan & Kestabilan & Jumlah waktu & $25 \%$ & \\
& Finger Dexterity & Kekuatan & Jumalah error & $25 \%$ & \\
\hline
\end{tabular}

Pengerjaan maze sebagai alat ukur performa keterampilan motorik halus ini akan dilakukan secara individual atau one-to-one test, dimana 1 orang subyek akan diarahkan dan didampingi oleh 1 orang tester/ administrator. Berdasakan hasil uji coba alat ukur, maze dalam penelitian ini dinyatakan valid dan reliabel dengan rentang koefisien korelasi aitem-total (rix) antara 0,298 sampai dengan 0,712 dan koefisien reliabilitas Alpha Cronbach $(\alpha)$ sebesar 0,812 .

\section{Metode pengumpulan data}

Pengumpulan data dalam penelitian ini dilakukan dengan cara melakukan pengukuran terhadap variabel tergantung penelitian yaitu keterampilan motorik halus. Pengumpulan data dilaksanakan sesuai dengan desain penelitian ini yaitu rancangan pre- test dan post-test pada satu kelompok (one-group pre-test post-test design). Pengukuran pertama akan dilakukan pada saat pre-test atau sebelum adanya perlakuan dan pengukuran kedua akan dilakukan pada saat post-test atau setelah adanya perlakuan ngulat tipat taluh pada subyek penelitian yang sama. Sehingga dengan adanya pre-test sebelum diberikannya perlakuan, maka hasil perlakuan dapat diketahui lebih akurat, dimana dapat dibandingkan dengan keadaan sebelum perlakuan (Sugiyono, 2012).

\section{Teknik Analisis Data}

Secara garis besar penelitian ini menggunaklan 2 jenis analisis statistik yaitu statistik deskriptif dan statistik inferensial. Statistik deskriptif hanya digunakan untuk mendeskripsikan data sampel dan tidak ingin membuat kesimpulan yang berlaku untuk populasi dimana sampel diambil. Sedangkan statistik inferensial adalah teknik statistik yang digunakan untuk menganalisis data sampel dan hasilnya yang kemudian diberlakukan untuk populasi secara random. Pengujian dilakukan dengan menggunakan teknik komputasi uji beda yaitu Paired T-Test one sample pada program Statistical Package for Social Sciences (SPSS) version 17.0 for windows (Trihendradi, 2011). Sebelum dilakukannya analisis uji beda pada hasil penelitian ini maka terdapat 2 (dua) jenis asumsi yang harus dipenuhi sebelum melakukan uji beda yakni uji normalitas dan uji homogenitas Penelitian ini menggunkan Paired-Sample T-test untuk pengujian hipotesis penelitian dengan alasan Paired-Sample T-test adalah uji komparasi yang mencakup dua pengukuran pada subjek yang sama (sampel bepasangan) terhadap suatu pengaruh atau perlakuan tertentu dengan melihat selisih pada rata-rata (Riduwan \& Sunarto, 2010;
Trihendradi, 2011). Uji hipotesis penelitian akan dilakukan dengan melakukan teknik komputasi Statistical Package for Social Sciences (SPSS) version 17.0 for windows.

\section{HASIL PENELITIAN}

Sebelum dilakukannya komputasi data hasil penelitian, peneliti melakukan beberapa tahapan sehingga data dapat diolah sesuai dengan tujuan penelitian ini. Tahapan tersebut antara lain:

1. Peneliti melakukan transformasi skor mentah (raw score) terhadap jumlah error dan waktu dalam pengerjaan maze masing-masing subyek penelitian yang diperoleh saat pre-test maupun post-test menjadi skor standar yaitu $\mathrm{Z}$ score.

2. Setelah data skor mentah ditransformasikan menjadi $\mathrm{Z}$ score, peneliti melakukan penjumlahan terhadap $\mathrm{Z}$ score error dan $Z$ score waktu masing- masing subyek penelitian. Hal ini dilakukan pada kedua data yang diperoleh baik pada data pre-test maupun post-test.

3. Selanjutnya, peneliti melakukan transformasi linier pada masing-masing skor individu dengan menambahkan nilai minimum pada pre-test dan post-test ditambah 1 ( $\mathrm{Z}$ score minimum + 1) (Azwar, 2010a).

Sebelum melakukan analisis uji beda T-test paired, terlebih dahulu perlu dilakukan uji asumsi yang meliputi uji normalitas dan uji homogenitas. Uji normalitas pada penelitian ini dilakukan melalui teknik komputasi one-sampel Kolmogorov-Smirnov Test dalam program SPSS version 17.0 for windows. Sebaran data akan dikatakan bedistribusi normal ketika nilai signifikansi lebih dari atau sama dengan 0,05.

Tabel 2.

Hasil Uji Normalitas

\begin{tabular}{lcc}
\hline & Pre-test & Post-test \\
$\mathrm{N}$ & 49 & 49 \\
Kolmogorov-Smirnov Z & 0,933 & 0,695 \\
Asymp. Sig. (2-tailed) & 0,349 & 0,720 \\
\hline
\end{tabular}

Tabel di atas menunjukkan bahwa variabel keterampilan motorik halus anak usia 6-7 tahun pada saat pretest dan post-test berdistribusi normal dengan nilai signifikansi di atas 0,05 . Variabel tergantung yaitu keterampilan motorik halus anak usia 6-7 tahun pada pre-test memiliki nilai $\mathrm{p}=$ 0,349 dan $p=0,720$ pada post-test. Uji asumsi kedua adalah uji homogenitas. Dapat dikatakan bahwa varian skor pada kelompok eksperimen memiliki varian yang sama atau homogen. Hal ini dikarenakan penelitian ini hanya menggunakan 1 kelompok eksperimen dengan subyek yang sama pada setiap tahapan penelitian, mulai dari pre-test, pemberian perlakuan hingga post-test.

Selanjutnya, peneliti melakukan uji beda pada data penelitian untuk menjawab hipotesis mayor penelitian ini. Hasil pengujian apakah terdapat pengaruh ngulat tipat 
taluh terhadap keterampilan motorik halus anak usia 6-7 tahun dapat dilihat pada tabel di bawah ini:

\begin{tabular}{|c|c|c|c|c|c|c|}
\hline \multicolumn{7}{|c|}{$\begin{array}{c}\text { Tabel 3. Hasil } \\
\text { Uji Beda }\end{array}$} \\
\hline \multirow[b]{2}{*}{ Pre-test-Post test } & Mean & Std. D & ation & $\mathrm{t}$ & $\mathrm{df}$ & Sig. (2-tailed) \\
\hline & 1,058 & & 1,121 & 6,603 & 48 & 0,000 \\
\hline & Korelas & $\begin{array}{l}\text { Tabe } \\
\text { Sampe }\end{array}$ & erpasa & & & \\
\hline & & $\mathrm{N}$ & Corre & tion & Sig. & \\
\hline Pre-te & Post-test & 49 & 0,4 & & 0,000 & \\
\hline
\end{tabular}

Tabel 3 menggambarkan selisih mean yang bernilai positif menunjukkan bahwa skor post-test memiliki nilai mean yang lebih rendah dibandingkan dengan pre-test. Selain itu, hasil pengujian juga memperoleh nilai t hitung sebesar 6,603 dengan signifikansi sebesar $0,00(\mathrm{p}<0,025)$. Nilai t hitung pada hasil pengujian lebih besar daripada $t$ tabel dimana nilai $t$ tabel untuk df $(\mathrm{N}-1)=48$ adalah 1,677. Hasil tersebut menunjukkan bahwa terdapat perbedaan yang signifikan pada nilai rata-rata sebelum dan sesudah perlakuan ngulat tipat taluh. Dengan kata lain terdapat pengaruh ngulat tipat taluh terhadap keterampilan motorik halus anak usia 6-7 tahun.

Sedangkan tabel 4 menggambarkan korelasi atau hubungan antar variabel penelitian yaitu keterampilan motorik halus anak usia 6-7 tahun dimana adanya korelasi yang signifikan karena nilai signifikansi memiliki nilai di bawah $0,05 \quad(\mathrm{p}<0,05)$. Berdasarkan pedoman interpretasi terhadap koefisien korelasi yang dikemukakan oleh Sugiyono (2012b), hasil yang terlihat adalah adanya hubungan dengan koefisien korelasi sebesar 0,484 (r=0,484). Hal ini menunjukkan bahwa variabel ngulat tipat taluh dapat menjelaskan atau mempengaruhi keterampilan motorik halus sebesar 23,42\% (R2=0,2342).

Peneliti selanjutnya melakukan pengkategorisasian pada hasil penelitian tersebut baik pada data pre-test maupun post-test terhadap performa keterampilan motorik halus anak usia 6-7 tahun. Sistem kategorisasi yang digunakan adalah kategorisasi jenjang dalam satuan kontinum. Kategorisasi dilakukan untuk mengelompokkan subyek ke dalam kategori-kategori terpisah secara berjenjang. Kontinum terdiri dari 5 jenjang yang bergerak dari sangat buruk ke sangat baik. Peneliti menggunakan kategorisasi normatif berdasarkan skor teoritis atau populasi yang diambil dari skor uji coba alat ukur keterampilan motorik halus anak usia 6-7 tahun.

Tabel 5.

Skor Teoritik Keterampilan Motorik Halus Anak Usia 6-7 Tahun

$\begin{array}{cccc}\text { Minimum } & \text { Maximum } & \text { Mean } & \text { Standar Deviasi } \\ 1.00 & 7.11 & 2.8700 & 1.283\end{array}$

Berdasarkan hasil uji coba yang dilakukan sebagai skor normatif maka ditemukan skor minimum adalah 1,00; skor maksimum adalah 7,11; mean $(\mu)$ sebesar 2,87; dan standar deviasi $(\sigma)$ adalah 1,283. Dengan demikian menurut Azwar (2012) kategori normatif skala pengukuran keterampilan motorik halus adalah sebagai berikut:
Tabel 6. Kategorisasi Skor Normatif

\begin{tabular}{cc}
\hline Rumus & Kategorisasi Skor \\
\hline $\mathbf{X} \leq(\boldsymbol{\mu}-\mathbf{1 , 5} \boldsymbol{\sigma})$ & Sangat Rendah \\
$(\boldsymbol{\mu}-\mathbf{1 , 5} \boldsymbol{\sigma})<\mathbf{X} \leq(\boldsymbol{\mu}-\mathbf{0 , 5} \boldsymbol{\sigma})$ & Rendah \\
$(\boldsymbol{\mu}-\mathbf{0 , 5} \boldsymbol{\sigma})<\mathbf{X} \leq(\boldsymbol{\mu}+\mathbf{0 , 5} \boldsymbol{\sigma})$ & Sedang \\
$(\boldsymbol{\mu}+\mathbf{0 , 5} \boldsymbol{\sigma})<\mathbf{X} \leq(\boldsymbol{\mu}+\mathbf{1 , 5} \boldsymbol{\sigma})$ & Tinggi \\
$(\boldsymbol{\mu}+\mathbf{1 , 5} \boldsymbol{\sigma})<\mathbf{X}$ & Sangat Tinggi \\
\hline
\end{tabular}

Maka berdasarkan rumus di atas, kategorisasi skor maze adalah sebagai berikut:

\begin{tabular}{|c|c|c|}
\hline \multicolumn{3}{|c|}{$\begin{array}{c}\text { Tabel 7. Kategorisasi } \\
\text { Skor Maze }\end{array}$} \\
\hline Skor & Kategorisasi Skor maze & $\begin{array}{c}\text { Kategorisasi keterampilan } \\
\text { motorik halus* }\end{array}$ \\
\hline$X \leq 0,95$ & Sangat Rendah & Sangat Baik \\
\hline $0,95<X \leq 2,23$ & Rendah & Baik \\
\hline $2,23<X \leq 3,51$ & Sedang & Sedang \\
\hline $3,51<X \leq 4,79$ & Tinggi & Buruk \\
\hline $4,79<X$ & Sangat Tinggi & Sangat Buruk \\
\hline
\end{tabular}

*Kategorisasi keterampilan motorik halus merupakan pengkategorian berdasarkan skor maze yang diperoleh dan bukan merupakan atribut ciri-ciri klinis.

Kategorisasi skor maze memiliki 5 (lima) rentangan yaitu sangat rendah, rendah, sedang, tinggi, dan sangat tinggi. Karena berdasarkan sistem skoring yang digunakan dalam penelitian ini menyatakan bahwa semakin tinggi skor maze yang diperoleh subyek penelitian maka semakin buruk keterampilan motorik halus yang dimiliki. Sedangkan jika semakin rendah skor maze yang diperoleh maka semakin baik keterampilan motorik halus yang dimiliki subyek penelitian. Maka kategorisasi antara skor maze dan keterampilan motorik halus berbanding terbalik, dimana kategorisasi keterampilan motorik halus bergerak dari rentangan sangat baik, baik, sedang, buruk, dan sangat buruk.

Berikut ini adalah frekuensi sebaran data berdasarkan rentangan kategorisasi yang telah dibuat.

\begin{tabular}{cccccc}
\multicolumn{5}{c}{ Tabel 8. } \\
\multicolumn{5}{c}{ Hasil Kategorisasi Skor Pre-test \& Post-test } \\
\hline Skor maze & Keterampilan & \multicolumn{2}{c}{ Pre-test } & \multicolumn{2}{c}{ Post-test } \\
& motorik halus & Frekuensi & Presentase & Frekuensi & Presentase \\
Sangat rendah & Sangat baik & - & $0 \%$ & - & $0 \%$ \\
Rendah & baik & 2 orang & $4,1 \%$ & 14 orang & $28,6 \%$ \\
Sedang & sedang & 23 orang & $46,9 \%$ & 27 orang & $55,1 \%$ \\
Tinggi & buruk & 13 orang & $26,5 \%$ & 8 orang & $16,3 \%$ \\
sangat tinggi & sangat buruk & 11 orang & $22,4 \%$ & - & $0 \%$ \\
\multicolumn{2}{c}{ Jumlah } & 49 orang & $100 \%$ & 49 orang & $100 \%$ \\
\hline
\end{tabular}

Tabel di atas menjelaskan bahwa dalam penelitian ini tidak ada subyek yang memiliki kategorisasi keterampilan motorik halus sangat baik, pada kondisi sebelum maupun setelah perlakuan. Pada pre-test hanya terdapat 2 orang subyek yang memiliki keterampilan motorik halus baik dengan persentase 4,1\%, 23 orang dalam kategori sedang (46,9\%), 13 orang dengan kategori buruk $(26,5 \%)$ dan 11 orang atau sekitar 22,4\% orang subyek berada dalam kategori keterampilan motorik halus yang sangat buruk. Sedangkan pada post-test terlihat adanya peningkatan keterampilan motorik halus dimana tidak adanya subyek penelitian yang tergolong ke dalam kategori memiliki keterampilan motorik halus yang sangat buruk. Dengan kata lain setelah adanya perlakuan ngulat tipat taluh pada subyek penelitian terjadi peningkatan keterampilan motorik halus yang cukup baik pada 
subyek penelitian, dimana setelah adanya perlakuan tidak ada lagi subyek yang berada pada kategori keterampilan motorik halus yang sangat buruk dan peningkatan yang pesat pada kategori keterampilan motorik halus yang baik dari hanya $4,1 \%$ menjadi $28,6 \%$. Peningkatan keterampilan motorik halus pada subyek penelitian dapat dilihat pada grafik di bawah ini:

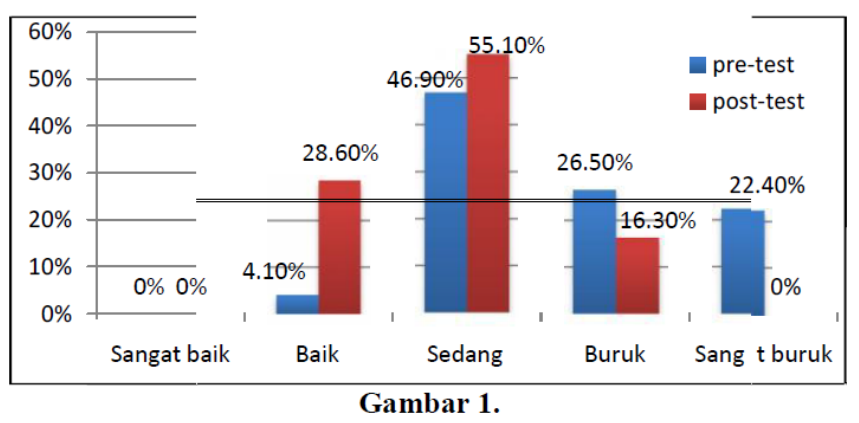

Grafik Peningkatan Keterampilan Motorik Halus Total

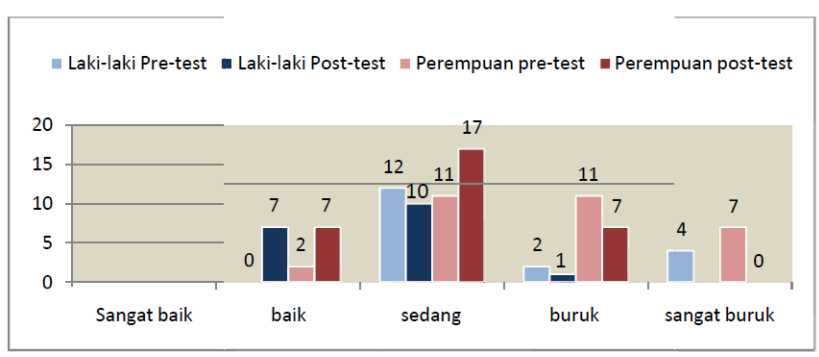

Gambar 2.

Grafik Peningkatan Keterampilan Motorik Halus Berdasarkan Jenis Kelamin

Peneliti juga melakukan pengkategorisasian keterampilan motorik halus subyek penelitian yang dibedakan berdasarkan jenis kelamin subyek. Pada kondisi post-test tidak diterdapat subyek yang tergolong ke dalam kategori keterampilan motorik halus sangat buruk. Peningkatan yang sangat pesat terlihat pada subyek laki-laki, dimana setelah adanya perlakuan ngulat tipat taluh terdapat 7 orang subyek berada dalam kategori keterampilan motorik halus baik. Peningkatan juga dialami oleh subyek perempuan dimana tidak terdapat satu orang subyek pun yang berada dalam kategori keteampilan motorik halus sangat buruk.

Hasil penelitian pengaruh ngulat tipat taluh terhadap keterampilan motorik halus juga dikategorisasikan berdasarkan usia subyek penelitian guna memperkaya hasil analisa data penelitian. Adapun hasil kategorisasi keterampilan motorik halus dibedakan menjadi 3 kelompok yakni usia 6-6,5 tahun, 6,51-7,0 tahun, dan 7,01-7,5 tahun. Berikut adalah hasil pengkategorisasian keterampilan motorik halus subyek menurut usianya.

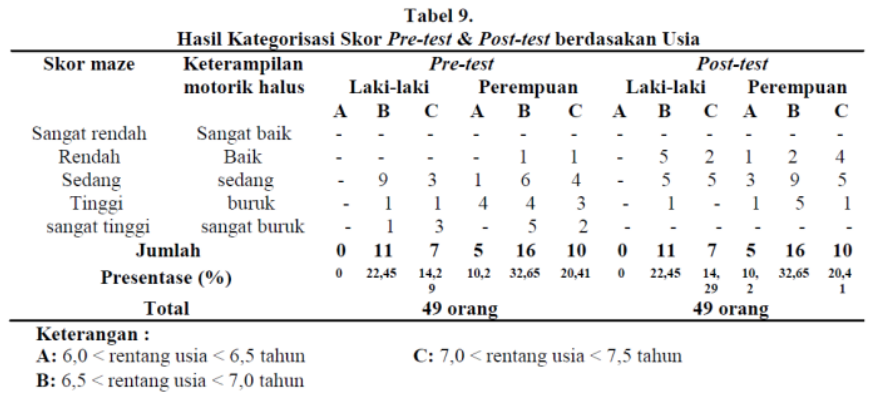

Berdasarkan data keseluruhan, pada subyek berjenis kelamin perempuan tersebar dalam 3 kategorisasi usia dimana 5 orang pada rentang usia 6,00- 6,5 tahun, 16 orang pada rentang usia 6,51-7,00 tahun dan 10 orang pada rentang usia 7,01- 7,5 tahun. Pada pengukuran pre-test sebagian besar subyek berjenis kelamin laki-laki dengan rentang usia 6,51-7,0 tahun memiliki keterampilan motorik halus sedang yaitu sebanyak 9 orang dan masing-masing terdapat 1 orang dalam kategori keterampilan motorik halus buruk dan sangat buruk. Sedangkan pada rentang usia 7,01-7,5 tahun terdapat 3 orang subyek dalam ketegori keterampilan motorik halus sangat buruk dan sedang serta 1 orang subyek dalam kategori buruk. Sedangkan pada post-test terlihat bahwa subyek laki-laki mengalami peningkatan keterampilan motorik halus, baik pada rentangan usia 6,51-7,00 tahun maupun 7,01-7,50 tahun. Sebagian besar subyek penelitian mengalami penurunan nilai/ skor maze, namun tidak sampai mengubah kategori keterampilan motorik halus mereka. Tetapi terdapat satu orang subyek yang mengalami peningkatan skor maze dari kategori keterampilan motorik halus sedang menjadi buruk dengan selisih skor 0,43.

Saat pre-test pada kelompok subyek perempuan berusia 6,00- 6,5 tahun terdapat 4 orang memiliki keterampilan motorik halus buruk dan 1 orang memiliki keterampilan motorik halus sedang. Pada rentang usia 6,517,00 tahun terdapat 5 orang subyek perempuan yang berada pada kategori keterampilan motorik halus sangat buruk, 4 orang pada keterampilan motorik halus buruk, 6 orang pada keterampilan motorik halus sedang dan 1 orang dalam kategori baik. Sedangkan pada rentangan usia 7,01-7,5 tahun terdapat 2 orang pada kategori keterampilan motorik halus sangat buruk, 3 orang pada kategori buruk, 4 orang dalam kategori sedang dan 1 orang pada kategori baik.

Peningkatan keterampilan motorik halus dapat dibandingkan pada saat sebelum dan sesudah perlakuan dimana terjadi peningkatan menjadi 4 orang subyek perempuan yang memiliki kategori keterampilan motorik halus baik yang sebelumnya hanya terdapat 1 orang subyek perempuan dalam kelompok usia 7,0-7,5 tahun. Dapat disimpulkan bahwa tabel 9 menggambarkan adanya peningkatan keterampilan motorik halus terjadi pada setiap kelompok usia pada rentangan 6-7,5 tahun setelah adanya perlakuan ngulat tipat taluh. Peningkatan juga terjadi dan 
tersebar pada kelompok-kelompok usia yang ada meskipun tidak ada 1 subyek pun yang mengalami peningkatan menjadi kategori keterampilan motorik halus sangat baik.

Analisis data selanjutnya yang dilakukan pada penelitian ini adalah melakukan kembali uji beda untuk menjawab hipotesis minor penelitian ini. Hasil analisis statistik untuk melihat ada tidaknya perbedaan nilai rata-rata pada saat sebelum dan sesudah diberikan perlakuan ngulat tipat taluh berdasarkan aspek dan indikator keterampilan motorik halus, maka ditemukan hasil sebagai berikut:

Tabel 10.

Hasil Uji Beda berdasarkan Indikator Error pada Maze

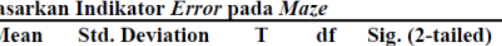
\begin{tabular}{llrrrr}
\hline Error pre-test - Error post-test & 5,26531 & 7,13786 & 5,164 & 48 & 0,000 \\
\hline
\end{tabular}

Tabel 10 menjelaskan bahwa adanya perbedaan nilai rata-rata pada indikator error atau tingkat kesalahan pada saat mengerjakan maze antara sebelum dan setelah adanya perlakuan ngulat tipat taluh. Hasil uji beda berdasarkan indikator error atau tingkat kesalahan ini menunjuk kepada aspek keakuratan dan kekuatan pada variabel keterampilan motorik halus. Hal ini dapat dilihat dari selisih mean sebesar 5,26531 yang bernilai positif menunjukkan bahwa jumlah error pada saat post-test memiliki nilai rata-rata yang lebih rendah dibandingkan jumlah error pada saat pre-test. Selain itu, hasil pengujian juga memperoleh nilai t hitung sebesar 5,164 dengan signifikansi sebesar 0,00 ( $\mathrm{p}<0,025)$. Nilai t hitung pada hasil pengujian lebih besar daripada tabel dimana nilai t tabel untuk df $(\mathrm{N}-1)$

$=48$ adalah 1,677 .

Tabel 11.

Korelasi Sampel Berpasangan berdasarkan Indikator Error pada Maze \begin{tabular}{cccc}
\hline & N & Correlation & Sig. \\
\hline Error pre-test - Error post-test & 49 & 0,297 & 0,038 \\
\hline
\end{tabular}

Sedangkan pada tabel 21 terlihat bahwa indikator error atau kesalahan pada maze saat pre-test dan post-test memiliki nilai koefisien korelasi sebesar 0,297 atau koefisien determinasi (R2) sebesar 0,088. Hal ini menunjukkan bahwa pelatihan ngulat tipat taluh memberikan sumbangan efektif sebesar 8,8\% terhadap aspek kekuatan dan keakuratan pada keterampilan motorik halus.

Analisis selanjutnya yang dilakukan oleh peneliti adalah melakukan uji beda terhadap nilai rata-rata berdasarkan indikator time atau waktu yang diperlukan saat mengerjakan maze. Indikator waktu pada maze menunjuk kepada aspek kecepatan dan kestabilan pada variabel keterampilan motorik halus saat pre-test dan post-test. Adapun hasil analisis data penelitian adalah sebagai berikut:

\begin{tabular}{rcrrrrr}
\multicolumn{7}{c}{ Tabel 12. } \\
Hasil Uji Beda berdasarkan Indikator Waktu pada Maze \\
\hline & Mean & Std. Deviation & t & df & Sig. (2-tailed) \\
\hline Waktu pre-test - Waktu post-test & 13,98673 & 52,15709 & 1,877 & 48 & 0,067 \\
\hline
\end{tabular}

Pada tabel 10 menjelaskan bahwa jumlah waktu yang diperlukan pada saat pengerjaan maze pada saat pre-test dan post-test memiliki selisih nilai rata-rata yaitu 13,98673. Dengan kata lain, waktu yang diperlukan untuk mengerjakan maze pada saat post-test memiliki nilai yang lebih rendah dibandingkan dengan pada saat pre-test. Namun berdasarkan hasil analisis uji beda di atas menunjukkan bahwa tidak adanya perbedaan yang signifikan antara nilai rata-rata jumlah waktu pada saat sebelum maupun setelah adanya perlakuan ngulat tipat taluh. Hal ini dapat terlihat dari taraf signifikansi sebesar $0,067(\mathrm{p}>0,025)$.

\section{PEMBAHASAN DAN KESIMPULAN}

Hasil analisis uji beda yang telah dilakukan menunjukkan, terdapat perbedaan nilai rata-rata sebelum perlakuan dengan nilai rata-rata setelah perlakuan ngulat tipat taluh. Hal ini dibuktikan dengan hasil uji beda diperoleh nilai signifikansi (2-tailed) $\leq 0,025(\alpha=0,025)$ yaitu 0,00 . Hasil analisis juga menunjukkan nilai $\mathrm{t}$ hitung pada penelitian ini adalah 6,603 lebih besar dari t tabel untuk df $(\mathrm{N}-1)=48$ adalah 1,677 (lihat tabel 3) sehingga dapat diputusan bahwa hipotesa alternatif $(\mathrm{Ha})$ di terima yaitu terdapat pengaruh ngulat tipat taluh terhadap keterampilan motorik halus anak usia 6-7 tahun secara signifikan. Hal ini juga memiliki arti terdapat perbedaan nilai rata-rata kelompok eksperimen antara sebelum dan sesudah adanya perlakuan ngulat tipat taluh. Hasil penelitian juga menunjukkan adanya korelasi yang signifikan antara perlakuan yang diberikan dengan hasil pengukuran yang sedang dimana terdapat pengaruh ngulat tipat taluh yang sedang terhadap keterampilan motorik halus dengan koefisien korelasi sebesar 0,484 (lihat tabel 4) dan $\mathrm{p}=0,00$. Koefisien ini juga dapat menjelaskan bahwa variabel ngulat tipat taluh dapat menjelaskan atau mempengaruhi keterampilan motorik halus anak sebesar $23,42 \%$.

Hasil tersebut menggambarkan bahwa terdapat peningkatan keterampilan motorik halus setelah adanya perlakuan ngulat tipat taluh pada anak usia 6-7 tahun dengan melihat selisih mean dan pengkategorisasian yang telah dilakukan sebelumnya. Sesuai dengan hasil pengkategorian, terjadi penurunan skor maze setelah adanya perlakuan atau menandakan adanya peningkatan keterampilan motorik halus dengan selisih 1,058 walaupun skor rerata antara pre dan posttest tetap berada pada rentangan kategori keterampilan motorik halus sedang. Hal ini sesuai dengan Budiari (2012) yang menyatakan bahwa ngulat tipat memiliki manfaat untuk melatih konsentrasi seseorang, memberikan manfaat kepuasan bagi pembuatnya, dan dapat melatih keterampilan jari-jari karena tingkat kerumitan dari tipat itu sendiri. Pernyataan lainnya juga dinyatakan oleh Karda (2003), ngulat tipat dapat melatih konsentrasi atau fokus dan ingatan seseorang. Selain memiliki fungsi untuk meningkatkan keterampilan jari-jari yang menjadisalah satu komponen dalam keterampilan motoric halus, konsentrasi juga diperlukan dalam pengembangan keterampilan motorik halus. Sesuai dengan definisi 
keterampilan motorik halus yang dikemukakan Santrock (2007) yaitu keterampilan motorik yang melibatkan kemampuan tangan, jari- jari dan lengan yang memerlukan konsentrasi, kontrol, kehati- hatian dan koordinasi otot tubuh satu sama lain. Menurut Hurlock (1995) terdapat aspek- aspek dalam keterampilan motorik halus yang dapat dikembangkan yaitu kecepatan, keakuratan, kestabilan, dan kekuatan. Pada aspek kekuatan dan keakuratan sangat diperlukan konsentrasi atau fokus yang baik. Sedangkan pada aspek kecepatan dan kestablilan lebih ditekankan pada waktu yang dapat tercermin dalam komponen finger dexterity atau ketangkasan jari/ tangan yang juga merupakan salah satu fungsi tipat selain secara sosial budaya, fungsi religius dan fungsi estetis.

Teori perkembangan lainnya yang medukung hasil penelitian ini adalah adalah teori kognitif sosial-budaya Vygotsky. Vygotsky (dalam Santrock, 2007) menekankan pada pentingnya interaksi sosial budaya dalam perkembangan kognitif anak. Pengetahuan pada anak tidak dihasilkan dari dalam individu itu sendiri melainkan lebih dibangun melalui interaksi dengan orang lain dan benda budayanya. Pada usia anak-anak madya/ pertengahan, anak secara formal berhubungan dengan dunia yang lebih luas dan kebudayaannya. Anak-anak usia ini akan mulai mempelajari dan mengenal kebudayaan mereka sendiri (Hughes, 2002; Santrock, 2002). Maka dapat dikatakan subyek penelitian yang tinggal di Bali akan jauh lebih mudah memahami instruksi dan mengenal benda yang menjadi kebudayaannya sendiri.

Hasil penelitian ini juga menunjukkan bahwa adanya pengaruh yang signifikan ngulat tipat taluh terhadap keterampilan motorik halus anak usia 6-7 tahun dengan hubungan yang sedang dan memiliki pengaruh sebesar $23,42 \%$. Hal ini memiliki arti bahwa ngulat tipat taluh memiliki pengaruh yang cukup/ sedang terhadap keterampilan motorik halus anak usia 6-7 tahun. Berdasarkan teori mengenai keterampilan motorik halus menurut Santrock (2007), perkembangan keterampilan motorik halus melibatkan proses yang aktif untuk membangun keterampilannya sehingga mencapai tujuan dalam batas yang ditentukan oleh tubuh anak dan lingkungannya. Maka banyak faktor yang bisa mempengaruhi keterampilan motorik halus anak dimana keterampilan motorik halus juga merupakan sebuah hasil kematangan (maturation) dan proses belajar. Dengan kata lain, diperlukan kesempatan belajar dan pemberian latihan pada individu yang tepat sesuai dengan tahapannya untuk mengembangkan keterampilannya secara optimal (Soetjiningsih, 2012). Selain itu hasil yang signifikan menunjukkan bahwa ada pengaruh yang positif terhadap keterampilan motorik halus anak usia 6-7 tahun yang didukung dengan adanya pernyataan bahwa perkembangan motorik halus anak juga dipengaruhi oleh budaya seseorang dan bergantung pada stimulus yang diberikan (Hughes, 2002;
Papalia, Olds \& Fieldman; 2009). Menurut Adolph dan Berger (dalam Soetjiningsih, 2012), seorang anak mendapatkan keterampilan-keterampilan motorik baru melalui kesempatan berlatih dari lingkungannya. Ngulat tipat taluh dapat dikatakan sebagai suatu latihan keterampilan motorik halus untuk anak yang merupakan salah satu kebudayaan di Bali.

Analisis yang menunjukkan adanya hasil signifikan namun dengan korelasi rendah ini juga serupa dengan pernyataan Kugler dan Turney (dalam Hughes, 2002) yang menyatakan bahwa perkembangan keterampilan motorik halus sangat dipengaruhi oleh dukungan maupun lingkungan, perkembangan otot dan tulang, gizi, dan kebutuhan akan tugas-tugas tertentu pada tangan yang tentunya akan meningkatkan keterampilan motorik halus. Proses pemberian perlakuan yang singkat dan jenis tipat yang memiliki tingkat kerumitan rendah memungkinkan terjadinya hubungan pengaruh yang sedang antara ngulat tipat taluh dengan keterampilan motorik halus anak usia 6-7 tahun. Kurang adanya kontrol terhadap beberapa faktor yang mempengaruhi keterampilan motorik halus seperti status gizi dan frekuensi aktivitas motorik halus. Pengaruh ngulat tipat taluh sebesar 23,42\% terhadap keterampilan motorik halus juga menyatakan bahwa masih terdapat beberapa hal yang perlu diperhatikan dalam penelitian ini. Hal ini bisa dipengaruhi oleh waktu pemberian perlakuan yang singkat, kesulitan kontrol terhadap subyek penelitian ketika berada diluar kondisi eksperimen, dan bervariasinya tingkat konsentrasi atau fokus dan rentang memori pada masing-masing subyek penelitian dalam menerima instruksi proses ngulat tipat taluh. Peningkatan keterampilan motorik halus yang tidak begitu besar setelah adanya perlakuan, kemungkinan diakibatkan karena efek jenuh dari subyek penelitian serta beberapa karakteristik anak usia awal sekolah dasar. Karakteristik tersebut antara lain anak usia awal sekolah dasar masih memiliki rentang konsentrasi yang tidak begitu lama, anak masih sering mengerjakan suatu hal secara teburu-buru dengan melihat kuantitas yang dihasilkan, dan adanya rasa ingin menonjol dibandingkan dengan teman- temanya (Wood, 1997). Jika ditinjau berdasarkan teori perkembangan kognitif Piaget, anak usia 6-7 tahun tergolong ke dalam tahapan praoperasional (preoperational stage) yang mencakup usia 2-7 tahun dan peralihan menuju tahap operasional konkret (concrete operational stage) yang mencakup usia 7-11 tahun (Santrock, 2007). Pada tahap ini anak belum dapat membayangkan sesuatu yang sangat abstrak dan masih diperlukannya modeling ketika menyelesaikan suatu permasalahan.

Ngulat tipat taluh merupakan salah satu kebudayaan di Bali yang dapat dikatakan sebagai suatu latihan keterampilan motorik halus. Berdasarkan analogi yang dilakukan, ngulat tipat taluh memiliki pondasi-pondasi dasar dalam pengembangan keterampilan motorik halus pada anak 
di setiap tahapannya. Menurut Isbell (2010a), beberapa pondasi dasar dalam pengembangan keterampilan motoric halus antara lain kesiapan perkembangan, postur yang baik dan seimbang, kekuatan bahu, kemampuan mengenggam, kontrol lengan bawah dan pergelangan tangan, penggunaan kedua tangan, dan koordinasi mata-tangan. Pondasi pertama yaitu kesiapan perkembangan menitik beratkan pada program penunjang yang disesuaikan dengan kemampuan anak pada fase perkembangannya. Ngulat tipat taluh memiliki tahapan pengerjaan yang mudah yang hanya terdiri dari 4 tahapan sehingga sesuai dengan anak awal sekolah dasar (Budiari, 2012). Kedua, postur yang baik dan seimbang memiliki arti dimana kegiatan motorik halus akan lebih mudah dilakukan ketika duduk dengan kaki menyentuh lantai serta posisi punggung yang tegak. Ketika anak melakukan kegiatan ngulat tipat taluh, mereka melakukannya dengan posisi duduk. Pondasi dasar ketiga, kekuatan bahu akan mendukung fungsi tangan anak menjadi lebih baik. Pada setiap tahapan proses ngulat tipat terdapat aktivitas yang menunjang kekuatan bahu seperti kondisi pada saat subyek merentangkan janur yang akan digunakan untuk membuat tipat. Pondasi keempat yaitu kemampuan menggenggam. Ketika membuat ketupat pada tahap pertama yaitu membuat 2 buah lingkaran anak menggunakan tangan kanan untuk menggenggam janur dan tangan kiri dalam posisi menggenggam, menahan lingkaran awal. Pondasi kelima, kontrol lengan bawah dan pergelangan tangan dimana anak harus mampu memutar lengan bawah yang menjadikan telapak tangan naik dan turun. Kemampuan ini dapat ditingkatkan melalui ngulat tipat taluh yang tercermin dalam setiap tahapannya, mulai dari tahap 1 sampai dengan 4 . Pondasi keenam adalah penggunaan kedua tangan dalam artian penggunaan kedua tangan untuk menyelesaikan aktivitas motorik halus. Pada proses ngulat tipat taluh semua rangkaian tahapannya melibatkan kedua tangan. Pondasi terakhir adalah eye-hand coordination atau koordinasi matatangan. Pondasi ini juga terdapat dalam proses ngulat tipat, dimana terlihat ketika subyek menganyam tipat mereka memerlukan koordinasi antara mata dan tangan sehingga sesuai dengan tahapan pembuatan tipat dan hasil yang diharapkan yaitu tipat taluh.

Perbedaan perkembangan keterampilan motorik halus juga terlihat pada subyek dengan jenis kelamin berbeda. Hasil penelitian menunjukkan bahwa peningkatan keterampilan motorik halus di dominasi oleh subyek perempuan dengan nilai pre-test yang lebih baik dan peningkatan yang pesat pada post-test, sekalipun hal ini juga terjadi pada subyek berjenis kelamin laki-laki. Hasil ini didukung dengan hasil penelitian mengenai keterampilan motorik halus yang juga menyatakan bahwa keterampilan motorik halus anak perempuan cenderung lebih baik dan melebihi anak laki-laki (Hughes, 2002; Santrock, 2007). Menurut Hughes (2002), anak perempuan lebih baik dalam melakukan aktivitas yang memerlukan ketelitian dan kecermatan dibandingkan dengan anak laki-laki yang biasanya lebih baik dalam keterampilan motorik kasar. Peningkatan yang juga pesat terlihat pada subyek laki-laki, dimana terjadi peningkatan sebanyak 7 orang subyek yang menjadi memiliki keterampilan motorik halus dengan ketegori baik setelah adanya perlakuan. Hal ini bisa saja dipengaruhi oleh kebudayaan seperti yang kemukakan oleh Vygotsky (dalam Santrock, 2007). Beberapa aktivitas anak laki-laki di Bali seperti membuat layang-layang, ogoh-ogoh, dan beberapa produk kesenian Bali lainnya hampir semuanya menggunakan kemampuan motorik halus.

Kategorisasi juga dilakukan berdasarkan usia subyek penelitian yang berusia dengan rentangan 6,0 tahun sampai dengan 7,5 tahun. Pengelompokan dilakukan menjadi 3 kelompok yaitu kelompok A, B, dan C. Berdasarkan teori perkembangan anak usia 6-7 tahun tergolong ke dalam masa anak-anak tengah (Hughes, 2002) dan akhir (Santrock, 2007). Perkembangan keterampilan motorik halus anak usia ini telah mengalami peningkatan dari usia sebelumnya. Perkembangannya akan semakin meningkat sesuai dengan tahapan usianya (Hughes, 2002). Hughes (2002) juga menyatakan ketika anak memasuki usia sekitar 7 tahun maka yang terjadi adalah peningkatan keterampilan motorik halus khususnya pada atribut eye-hand coordination dan finger dexterity. Namun yang terjadi dalam penelitian ini adalah pada skor pre-test, 3 orang subyek laki-laki (42,86\%) dengan rentang usia 7,01-7,5 memiliki keterampilan motorik halus sangat buruk. Jika dibandingkan dengan rentang usia 6,517,00 hanya terdapat 1 orang dari 11 orang laki-laki $(9,09 \%)$. Hasil lainnya yang terlihat adalah adanya penurunan keterampilan motorik halus pada salah 1 subyek laki-laki pada rentang usia 6,51-7,0 tahun. Hal ini kemungkinan terjadi akibat efek jenuh dari subyek penelitian pada saat proses pengumpulan data baik pre-test dan post-test, dimana pengerjaan maze pada masing-masing subyek tidak berlangsung secara serentak yang menjadikan beberapa subyek penelitian harus menunggu giliran untuk mengerjakan maze.

Perbedaan hasil penelitian ini dengan teori perkembangan yang telah dikemukakan di atas juga terjadi pada kelompok subyek berjenis kelamin perempuan pada rentang usia 6,00-6,50 tahun dimana kelompok ini memiliki keterampilan motorik halus yang lebih baik dibandingkan dengan rentang usia 6,51-7,50 tahun. Hal ini terlihat dari data hasil penelitian dimana tidak terdapat subyek pada kelompok usia 6,00-6,50 tahun yang memiliki kategori keterampilan motorik halus sangat buruk. Berbeda halnya dengan kelompok usia 6,51-7,00 tahun dan kelompok usia 7,01-7,5 tahun dimana terdapat 5 orang dan 2 orang yang memiliki kategori keterampilan motorik halus sangat buruk. Setelah adanya perlakuan ngulat tipat hasil penelitian 
menunjukkan adanya peningkatan keterampilan motorik halus anak usia 6-7 tahun pada kelompok laki-laki maupun perempuan. Menurut Susanto (2011), anak usia 6-7 tahun yang tergolong ke dalam masa sekolah dasar juga sering kali disebut sebagai masa pendidikan dan latihan panca indera.

Hasil analisis dari penelitian ini juga menyatakan bahwa adanya perbedaan yang signifikan antara nilai rata-rata sebelum dan sesudah adanya perlakuan ngulat tipat taluh pada indikator error atau kesalahan yang dibuat saat mengarjakan maze. Hal ini terlihat dari hasil uji beda dimana nilai t hitung lebih besar dari t tabel yaitu 5,164> 1,677 dengan nilai signifikansi $0,00 \quad(\mathrm{p}<0,025)$. Karena indikator error atau kesalahan saat mengerjakan maze mengacu kepada aspek kekuatan dan keakuratan pada keterampilan motorik halus maka dapat diambil keputusan bahwa hipotesis alternatif minor pertama dapat diterima dimana terdapat pengaruh ngulat tipat taluh terhadap aspek keakuratan dan kekuatan pada keterampilan motorik halus anak usia 6-7 tahun. Hal ini sejalan dengan kajian mengenai ngulat tipat taluh yang dikaitkan dengan 7 pondasai dasar dalam pengembangan keterampilan motorik halus dari Isbel (2010a). Terutama mengacu pada pondasi dasar ke tujuh yaitu eye-hand coordination atau koordinasi antara mata dan tangan. Saat ngulat tipat, sangat diperlukannya koordinasi antara mata dan tangan sehingga dapat mengasilkan bentuk ketupat yang diharapkan. Pada komponen eye-hand coordination akan lebih terlihat dari aspek keakuratan dan kekuatan pada keterampilan motorik halus. Namun hasil analisis menunjukkan bahwa pengaruh ngulat tipat taluh terhadap aspek kekuaan dan keakuratan hanya memiliki sumbangan efektif sebesar $8,8 \%$ atau terbilang rendah. Hal ini berkaitan dengan bahwa keterampilan motorik halus merupakan suatu keterampilan yang berkembang secara bersinergi antara setiap aspeknya, mulai dari keakuratan, kekuatan, kecepatan dan kestabilan (Hurlock, 1995).

Namun pada hasil uji beda yang dilakukan untuk menjawab hipotesis minor kedua menunjukkan hasil dimana taraf signifikansi sebesar 0,067 ( $p>0,025)$. Maka dapat diambil keputusan bahwa tidak ada pengaruh ngulat tipat taluh terhadap aspek kecepatan dan kestabilan pada keterampilan motorik halus. Meskipun pada hasil uji beda menunjukkan tidak adanya perbedaan yang signifikan, namun pada hasil korelasi sampel berpasangan berdasarkan indikator waktu yang menjadi indikator aspek kecepatan dan kestabilan pada keterampilan motorik halus, menunjukkan hasil yang siginifikan dengan nilai signifikansi yaitu $0,00 \quad(\mathrm{p}<0,05)$ dengan sumbangan efektif sebesar $60,06 \%$. Dapat dijelaskan lebih lanjut bahwa, ngulat tipat taluh memiliki nilai korelasi yang tinggi sehingga dapat menjelaskan aspek kecepatan dan kestabilan pada keterampilan motorik halus sebesar $60,06 \%$, namun tidak diperoleh hasil yang signifikan pada perbedaan jumlah waktu yang diperlukan untuk mengerjakan maze, baik sebelum dan setelah adanya perlakuan ngulat tipat taluh. Hal ini bisa disebabkan karena efek pemberian perlakuan yang belum terlihat efektif karena penelitian dilakukan dalam kurun waktu yang cukup singkat.

Kedua hasil penelitian mengenai hipotesis minor pada penelitian yang berkaitan dengan aspek pada keterampilan motorik halus dapat dijelaskan melalui beberapa teori mengenai perkembangan gerak dan belajar gerak. Hasil yang menunjukkan bahwa adanya pengaruh yang signifikan terhadap aspek keakuratan dan kekuatan pada keterampilan motorik halus dapat dijelaskan melalui teori perkembangan gerak yang menyatakan bahwa adanya pengaruh sosial atau lingkungan terhadap perkembangannya. Salah satu bentuk pengaruh sosial yang mungkin dialami adalah budaya sebagai suatu kebiasaan dalam konteks keluarga dan diluar keluarga yang dapat memberikan warna dalam keterampilan motorik seseorang (Ma'mun \& Saputra, 2000). Melihat tingkat korelasi antara ngulat tipat taluh dengan beberapa aspek keterampilan motorik halus yang cukup baik, menjadi suatu konteks budaya yang memiliki pengaruh terhadap aspek perkembangan gerak seseorang. Selain itu hasil sumbangan efektif yang rendah namun memiliki pengaruh terhadap aspek keakuratan dan kekuatan dan juga hasil yang tidak berpengaruh signifikan namun memiliki korelasi yang tinggi sangat berkaitan dengan teori mengenai latihan motorik dan keterampilan. Menurut Ma'mun dan Saputra (2000), keterampilan gerak akan dapat diperoleh dan dikuasai ketika adanya pembelajaran dan pelatihan yang terus menerus dalam kurun waktu tertentu. Selain itu menurut teori perkembangan Piaget dan perkembangan gerak, anak usia 6-7 tahun tercakup dalam tahapan pre-operational dimana pada usia ini anak belum mampu melakukan pemecahan masalah atau problem solving dengan baik. Berdasarkan kaitan antara perkembangan kognitif dengan perkembangan gerak, problem solving memiliki dampak yang penting terhadap keterampilan gerak seseorang.

Berdasarkan hasil penelitian ini dapat dinyatakan bahwa keterampilan motorik halus merupakan aspek perkembangan yang sangat penting selain perkembangan aspek kognitif yang akan memberikan peran dalam kehidupan seorang anak kedepannya. Ada baiknya untuk mempertimbangkan pengembangan aspek perkembangan anak yang disesuaikan dengan tahapan usia anak. Terutama pada anak usia 6-7 tahun yang tergolong dalam usia awal sekolah dasar, dimana kompetensi mereka sangat diperlukan dalam menyelesaikan tugas-tugas sekolahnya yang akan berdampak pada perkembangan aspek lainnya (Soetjiningsih, 2012). Pada usia ini anak berada dalam fase fase kerja keras versus rasa inferior (industry versus inferiority). Pada tahap ini, secara inisiatif anak akan berhubungan dengan pengalaman baru.

$$
\text { Jika anak mengalami keberhasilan }
$$
yang memuncak, maka anak akan melanjutkan pola sikap 
ketekunannya (Hughes, 2002). Namun ketika anak gagal dalam kompetensinya, memungkinkan munculnya perasaan inferior atau merasa tidak kompeten dan tidak produktif (Hughes, 2002; Santrock, 2007).

Sesuai dengan pemaparan hasil penelitian di atas maka dalam penelitian ini dapat disimpulkan bahwa 1.) terdapat pengaruh ngulat tipat taluh terhadap keterampilan motorik halus anak usia 6-7 tahun secara signifikan. 2.) Hasil penelitian menunjukkan variabel ngulat tipat taluh dapat meningkatkan keterampilan motorik halus anak usia 6-7 tahun dimana variabel ngulat tipat taluh menjelaskan keterampilan motorik halus anak usia 6-7 tahun sebesar 23,42 \%. 3.) Terdapat perbedaan nilai rata-rata antara pre-test dan post-test, dimana nilai kesalahan dan waktu yang diperlukan untuk mengerjakan maze saat post-test lebih rendah dibandingkan dengan saat pre-test. Namun dapat dijelaskan lebih jauh bahwa pada saat pre-test terdapat subyek yang memiliki keterampilan motorik halus sangat buruk yang lebih banyak dibandingkan saat post-test. Demikian halnya pada saat post-test, tidak ada satupun subyek penelitian yang memiliki keterampilan motorik halus sangat buruk setelah adanya perlakuan ngulat tipat taluh. 4.) Terdapat pengaruh ngulat tipat taluh terhadap aspek keakuratan dan kekuatan pada variabel keterampilan motorik halus yang terukur melalui indikator error atau kesalahan pada maze dengan sumbangan efektif sebesar $8,8 \%$. Namun tidak terdapat pengaruh ngulat tipat taluh secara signifikan terhadap aspek kecepatan dan kestabilan pada variabel keterampilan motorik halus yang terukur melalui indikator waktu pada maze.

\section{DAFTAR PUSTAKA}

Anna, L. K. (2012, Juni 13). Perlukah Mengajarkan Calistung di Usia Dini?. Diambil pada 15 Juni 2013, dari

Kompas.com: http://edukasi.kompas.com

/read/2012/06/13/1359517/Perlukah.Mengajarkan.Calistung.di.Usia. Dini

Anandakusuma, Sri Reshi (1986). Kamus bahasa Bali ; BaliIndonesia, Indonesia-Bali.

Graha Pengajaran : CV. Kayumas Agung.

Azwar, S. (2000, Juli). Asumsi-asumsi dalam inferensi statistika. Yogyakarta. Azwar, S. (2004). Metode penelitian. Yogyakarta: Pustaka pelajar.

Azwar, S. (2010a). Dasar-dasar psikometri. Yogyakarta: Pustaka Pelajar. Azwar, S. (2010b). Reliabilitas dan validitas. Yogyakarta: Pustaka Pelajar. Azwar, S. (2012). Penyusunan skala psikologi. Yogyakarta: Pustaka Pelajar. Budiari, N. M. (2012, Oktober 15). (M. P. Bajirani, Interviewer)

Creswell, J. W. (2010). Reseach design; pendekatan kualitatif, kuantitatif dan mixed; 3rd edition. Yogyakarta: Pustaka Pelajar.
Fender, Katya P. \& Majnemer, Annette. (2007). Handwriting development, competency, and intervention. [Electronic version]. Developmental Medicine \& Child Neurology 2007, 49: 312-317. Diambil pada 10 Oktober 2012 dari http://onlinelibrary.wiley.com/doi/10.1111/j.14698749.2007.00312.x/pdf.

Hartingsveld, Margo J. Van., Groot, Imelda, J. M. De., Aarts, Pauline, B.M., \& Sanden, Maria W.G. N. Van Der. (2011). Standardized tests of handwriting readiness: a systematic review of the literature. [Electronic version] Journal compilation, Developmental medicine and child neurology, 506-515. Diambil pada 10 Oktober 2012 dari http://onlinelibrary.wiley.com/doi/10.1111/j.1469-

8749.2010.03895.x/pdf.

Hughes, Laurel. (2002). Paving pathways: Child and adolescent development. United States of America: Wadsworth, Thomson Learning.

Hurlock, E. (1980). Developmental psychology: a life-span approach. New York: McGraw-Hill, Companies, Inc.

Hurlock, E. (1995). Perkembangan anak, jilid 1 edisi keenam. Jakarta: Erlangga.

Isbell, Christy. (2010a). Everyday play: Fine motor activities for young children. Columbia Pike: Gryphon House.

Isbell, Christy. (2010b). Mightyf fine motor fun: Fun games to develop the fine motor skills your child need for school. Columbia Pike: Gryphon House.

Kantha, T., Boonchai, P., \& Krairach, T. (2012). Isan Folk Game Conservation for Fine- Motor Skills Development in Pre-School Children. American Journal of Scientific Research, ISSN 1450223X Issue $53,5-14$.

Karda, I Made (2003). Filsafat dan simbolisme ketupat sebuah kajian estetik. Mudra (3) 13. 36-49.

Kerlinger, F. N. (2006). Asas-asas penelitian behavioral. Yogyakarta: Gadjah Mada University Press.

Kusuma, I Gusti A. Kamus bahasa bali-indonesia; jilid 1. Denpasar: Usaha Penerbitan Bali Mas.

Laoakka, S., Karnjanangkura, D., \& Suwapeat, N. (2009). Isan cfgildren folk toys: application and development for appropriate age-group of child growth. Medwel Journals; the social science 4 (2) , 203-206.

Lee, Steven W. (eds.). (2005). Encyclopedia of school psychology. United States of America: Sage publication.[Electronic version]. Diambil pada 20 Oktober 2012 dari http://books.google.co.id/books?id=Ry6jQgn6QmYC\&pg=PA3 
$36 \& \mathrm{dq}=$

fine+motor+skill+steven + W.\&hl=id\&sa=X\&ei=fceRUaXYOI3 ntQaM6oG4Cw\& ved=0CCoQ6AEwAA

Ma'mun, A., \& Saputra, Y. M. (2000). Perkembangan gerak dan belajar gerak. Jakarta: Departemen Pendidikan dan Kebudayaan, Direktorat Pendidikan Dasar dan Menengah.

Munawwaroh. (2012, 20 Maret). Komnas Anak: PAUD Bikin Anak Balita Stres. Diambil pada $10 \quad$ Juni 2013, dari Tempo.co: $\quad$ http://www.tempo.co/read/ news/2012/03/20/079391570/Komnas-Anak-PAUD-BikinAnak-Balita-Stres

Myers, A., \& Hansen, C. (2006). Experimental psychology (6th ed.). United State of America: Thomson Wadsworth.

Nelson, S. L., \& Jaskiewicz, J. L. (2012, 5 Juli). medscape reference. [Electronic version] Diambil pada 4 Oktober 2012, dari Motor Skills Disorder : http://emedicine.medscape.com/article/915251overview\#aw2aab6b2b3

North Coach Beginning Teacher Program (2008). North Coach Beginning Teacher Program. [Electronic version]. Diambil pada November 2012, dari http://www.ncbtp.org/pdf_documents/para/handouts/aug_2009

/05_fine_motor_skills.pdf

Ngoerah, I Gusti Ayu Oka Arwati (1998). Mari membuat ketupat. Denpasar: Upada Sastra. Papalia, D., Olds, S., \& Feldman, R. (2008). Human development. New York: McGraw Hill Companies, Inc.

Papalia, Diane E., Olds, Sally W., \& Fieldmean, Ruth D., (2009). Human development (11th ed.). New York: McGraw-Hill.

Pemberdayaan dan Kesejahteraan Keluarga Kota Denpasar. (2009). Denpasar mendominasi lomba kewanitaan [Electronic version]. Diambil pada 10 Oktober 2012 dari

http://www.denpasarkota.go.id/instansi/?cid==YzN\&s=i_berita \&id $=1666$

Pullen, W. D. (2011, 24 Januari). Maze Algorithms. Diambil pada 12 Januari 2013 dari Labyrinth: http://www.astrolog.org/labyrnth.htm

Puspayanti, Theresia (2009, 29 April). Mainan Tradisional Masuk Sekolah [Electronic version]. Kompas.com Diambil pada 7 Oktober 2012 dari http://perempuan.kompas.com/read/xml/2009/04/29/15020052/ Mainan.Tradisiona 1.Masuk.Sekolah

Rabani, M. E. (2011). Algoritma prim sebagai maze generation algorithm. Bandung: Makalah IF2091 Struktur Diskrit. [Electronic version]. Diambil pada 3 Januari 2013 dari http://informatika.stei.itb.ac.id/ rinaldi.munir/Matdis/20112012/Makalah2011/Makalah-IF2091-2011-064.pdf

Raras, Niken Tambang (2007). Fungsi dan cara membuat tipat versi Jawa-Bali. Surabaya: Pāramitha.

Santrock, John, W. (2002). Life-span development: Perkembangan masa hidup, jilid I (5th ed.) (Juda Damanik, Achmad Chusairi, Trans.). Jakarta: Erlangga.

Santrock, J. (2007). Perkembangan anak; Edisi ke sebelas Jilid I. Jakarta: Erlangga. Santrock, John, W., (2012). Educational Psychology: Physical and cognitive development

[Electronic version]. Online Learning Centre, 32-65 Diambil pada 10 Oktober 2012 dari

http://highered.mcgrawhill.com/sites/dl/free/0070909695/12022 0/ santrock_edpsych_ch02.pdf.

Setyani, Christina Andhika. (2012, 4 Juni). Bermain Bantu Rangsang Kemampuan Motorik Anak [Electronic version]. Kompas.com. Diambil pada 7 Oktober 2012 dari http://female.kompas.com/read/2012/06/04/16223170/Bermain. Bantu. Rangsang.Kemampuan.Motorik.Anak.

Shaffer, David R., Kipp, K., Wood, E., \& Wiloughby, T. (2010). Developmental psychology: Childhood and adolescence (4th ed). United States: Nelson education.

Soetjiningsih, C. H. (2012). Perkembangan anak sejak pertumbuihan sampai dengan kanak-kanak akhir. Jakarta: Prenada Medoa Group.

Stoeger, H., Zigegler, A., \& Martzog, P. (2008). Deficits in fine motor skill as an important factor in the identification of gifted underachievers in primary school. Psychology Science Quarterly, Volume 50, (2), 134-146.

Sugiyono. (2012a). Metode Penelitian Kombinasi (Mixed Method). Bandung: Alfabeta. Sugiyono. (2012b). Statistika untuk penelitian. Bandung: Alfabeta.

Surayin, I. A. (1999). Bahan dan bentuk sesajen: Seri II upakara Yadnya. Denpasar: Upada Sastra .

Suryabrata, S. (2000). Metodologi Penelitian. Jakarta: PT Raja Grafindo Persada.

Susanto, Ahmad. (2011). Perkembangan anak usia dini: Pengantar dalam berbagai aspeknya. Jakarta: Kencana.

Trihendradi, C. (2011). Langkah mudah melakukan analisis statistik menggunkaan SPSS 19. Yogyakarta: ANDI.

Virginia School Health Guidelines. (1994). Early periodic screening. Diambil pada 3 Desember 2012, dari /www.doe.virginia.gov: http://www.doe.virginia.gov/support/ health_medical/virginia_school_health_guidelines/early_periodi c_screening.pdf 
M. P. D. Bajirani dan L. K. P. A. Susilawati

Wood, C. (1997). Yardsticks: Children in the classroom age 4-14, a resource for parents \& teacher. Northeast: Northeast Foundation for Children.

Woodfield, L. (2004). Physical development in the early years. New York: Continuum International Publishing Group.

Ziegler, A. (2010). How fine motor skills influence the assessment of high abilities and underachievement in math. Journal for the Education of the Gifted: Vol. 34, No. 2 195-219. 